\title{
Overwinter habitat selection by Antarctic krill under varying sea-ice conditions: implications for top predators and fishery management
}

\author{
Christian S. Reiss ${ }^{1, *}$, Anthony Cossio ${ }^{1}$, Jarrod A. Santora ${ }^{2}$, Kimberly S. Dietrich1, \\ Alison Murray ${ }^{3}$, B. Greg Mitchell ${ }^{4}$, Jennifer Walsh ${ }^{1}$, Elliot L. Weiss ${ }^{4}$, Carla Gimpel ${ }^{5}$, \\ Christopher D. Jones ${ }^{1}$, George M. Watters ${ }^{1}$ \\ ${ }^{1}$ Antarctic Ecosystem Research Division, Southwest Fisheries Science Center, La Jolla, CA 92037, USA \\ ${ }^{2}$ Department of Applied Mathematics and Statistics, Center for Stock Assessment Research, University of California, \\ Santa Cruz, CA 95060, USA \\ ${ }^{3}$ Desert Research Institute, University of Nevada, Reno, NV 89096, USA \\ ${ }^{4}$ Scripps Institution of Oceanography, University of California, San Diego, La Jolla, CA 92093, USA \\ ${ }^{5}$ Center for Microbial Ecology Research and Education, University of Hawaii, HI 96822, USA
}

ABSTRACT: Climate change will affect Antarctic krill Euphausia superba, krill-dependent predators, and fisheries in the Southern Ocean as areas typically covered by sea ice become ice-free in some winters. Research cruises conducted around the South Shetland Islands of the Antarctic Peninsula during winters with contrasting ice conditions provide the first acoustic estimates of krill biomass, habitat use, and association with top predators to examine potential interactions with the krill fishery. Krill abundance was very low in offshore waters during all winters. In Bransfield Strait, median krill abundance was an order of magnitude higher $\left(8 \mathrm{krill} \mathrm{m}^{-2}\right)$ compared to summer $\left(0.25 \mathrm{krill} \mathrm{m}^{-2}\right)$, and this pattern was observed in all winters regardless of ice cover. Acoustic estimates of krill biomass were also an order of magnitude higher ( 5500 000 metric tons [t] in 2014) than a 15 yr summer average (520 000 t). Looking at krilldependent predators, during winter, crabeater seals Lobodon carcinophagus were concentrated in Bransfield Strait where ice provided habitat, while Antarctic fur seals Arctocephalus gazella were more broadly distributed. Krill overwinter in coastal basin environments independent of ice and primary production and in an area that is becoming more frequently icefree. While long-term projections of climate change have focused on changing krill habitat and productivity declines, more immediate impacts of ongoing climate change include increased risks of negative fishery-krill-predator interactions, alteration of upper trophic level community structure, and changes in the pelagic ecology of this system. Development of

*Corresponding author: christian.reiss@noaa.gov

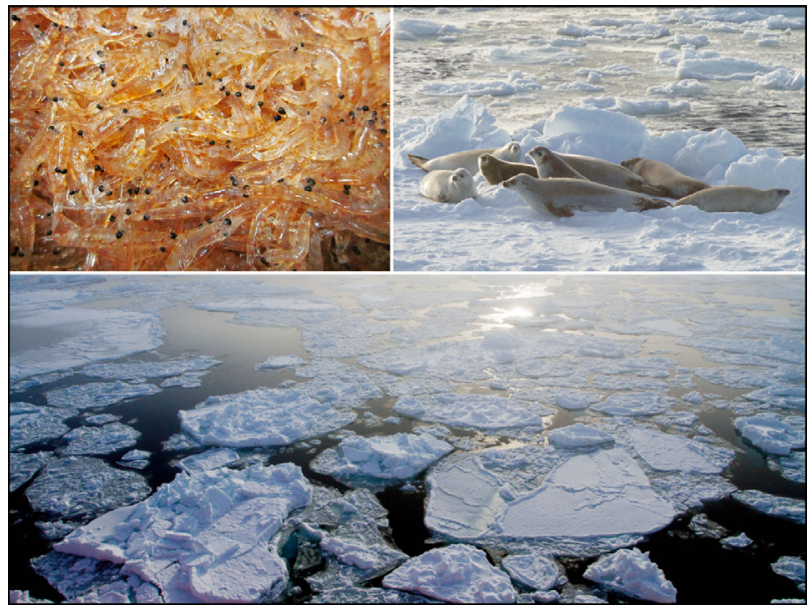

Changes in sea-ice coverage will impact trophic interactions during the Antarctic winter.

Photos: Jennifer Walsh and Abraham Borker

management strategies to mitigate the increased risk to krill populations and their dependent predators over management timescales will be necessary to minimize the impacts of long-term climate change.

KEY WORDS: Southern Ocean - Antarctic krill · Fishery interactions - Sea ice - Commission for the Conservation of Antarctic Marine Living Resources · CCAMLR $\cdot$ Ocean warming

(c) The authors 2017. Open Access under Creative Commons by Attribution Licence. Use, distribution and reproduction are unrestricted. Authors and original publication must be credited. 


\section{INTRODUCTION}

Antarctic krill Euphausia superba is a key species in the Southern Ocean and is a principal link between phytoplankton production and upper trophic levels (Atkinson et al. 2008). They are important for nutrient cycling and carbon flux through the ecosystem (Laws 1977, Smetacek \& Nicol 2005), and their massive biomass supports an important commercial fishery (Nicol et al. 2012, Nicol \& Foster 2016). A number of studies have shown a strong relationship between seasonal sea-ice extent and recruitment success of krill, emphasizing the importance of physical processes in winter (Loeb et al. 1997, Atkinson et al. 2004, Ross et al. 2014, Saba et al. 2014). In the last quarter of the 20th century, krill densities across the Southwest Atlantic sector of the Southern Ocean, near the Antarctic Peninsula, have reportedly declined between 36 and $80 \%$, concomitant with declines in sea-ice extent and duration (Atkinson et al. 2004). The decline in sea ice, driven by climatic changes in atmospheric heat transport, has presumably led to concomitant changes in quality and quantity of overwinter habitat for krill at all life stages (but see Melbourne-Thomas et al. 2016). Such changes in the physical environment are likely to continue in the future and result in an increased number of low-ice and ice-free years (Stammerjohn et al. 2008b). This may have negative impacts on the food web (Flores et al. 2012a,b) and ice-dependent krill predators (Siniff et al. 2008, Dunn et al. 2011, Santora 2014), and could increase fishery interactions (Nicol et al. 2012).

Along the Antarctic Peninsula, krill are distributed on the shelf and into oceanic waters during summer, where larger krill spawn (Siegel et al. 2013) and where the fishery historically exploited large temporally stable aggregations (Nicol \& Foster 2016). At-sea observations and surveys have related patterns of habitat use by birds and mammals to the distribution of krill hotspots and krill size distribution (Santora et al. 2012, Santora \& Veit 2013), while studies focused on land-based predators have examined summer reproductive success of birds and mammals, including Antarctic fur seals Arctocephalus gazella (Croll \& Tershy 1998) and penguins (Trivelpiece et al. 2011), in relation to krill abundance and demographic patterns. These studies have shown that the spatial distribution of krill during summer is a major factor influencing the distribution of predators and thus the spatial structure of ecological interactions.
There are considerable gaps in understanding how the pelagic ecosystem of the Southern Ocean is restructured from summer to winter, especially now that climate change is impacting the initialization of ice formation and duration (Stammerjohn et al. $2008 b)$. The seasonal abandonment by krill of offshore waters (Siegel 1988), where $90 \%$ of the krill biomass reside during austral summer (Atkinson et al. 2009), and the hypothesized shelfward migration during autumn and winter (Mackintosh 1972, Siegel 1988), suggest that krill density should increase greatly in coastal and near-shore environments during winter. However, contradictory evidence exists for the magnitude of the concentration of krill in coastal areas (Mackintosh 1972, Stepnik 1982, Siegel 1988, 2005, Zhou et al. 1994, Lascara et al. 1999, Zhou \& Dorland 2004, Lawson et al. 2008a,b, Atkinson et al. 2009, Nowacek et al. 2011), with different results based on timing, sampling gear, and conditions. Additionally, recent effort has focused on the importance of deep-ocean (>1500 m) benthic environments as overwintering habitats (Atkinson et al. 2009, Schmidt et al. 2011) that might harbor a large fraction of krill during winter. Clearly distinguishing the magnitude of coastal concentration is necessary to understand krill population dynamics and life history tradeoffs, and also to understand availability of krill for krill-dependent predators (Ribic et al. 2008) as well as the fishery.

There is a critical need to better understand the winter structure of these ecologically-important and climatically-vulnerable ecosystems, especially given the observed declines in sea-ice extent and duration (Stammerjohn et al. 2008a), estimated declines in krill abundance (Atkinson et al. 2004), increased localized fishing pressure during autumn and winter (Nicol \& Foster 2016), and potential interaction with nonmonitored species. Here we use a multidisciplinary data set from 3 winter surveys to examine the relationships among the spatial distribution of predators, the abundance and biomass of krill, sea ice, and primary production around the northern Antarctic Peninsula. Specifically, we test whether: (1) the relative importance to krill of areas in the Antarctic Peninsula varies from summer to winter (i.e. seasonal migration hypothesis), and (2) krill-predator habitat use is dependent on sea-ice concentration and krill biomass. We provide the first-ever winter acoustic estimates of krill biomass in this region during a relatively ice-free season using the latest algorithms (CCAMLR 2010, Fielding et al. 2011) and compare these estimates with historical data collected during summer. 


\section{MATERIALS AND METHODS}

\section{Study area}

The northern Antarctic Peninsula region of the Southern Ocean is a bathymetrically-complex area with a variety of water currents that converge and mix around the South Shetland Islands, the tip of the peninsula at Joinville Island (JI), and within Bransfield Strait (BS; our Fig. 1; Jiang et al. 2013). In the BS, cold salty Weddell-shelf water enters near JI and flows south along the northern coast of the Antarctic Peninsula (von Gyldenfeldt et al. 2002, Thompson et al. 2009, Thompson \& Youngs 2013). Water from the Antarctic Circumpolar Current (ACC; Bellingshausen surface water, and Upper Circumpolar Deep Water) enters the BS from the southwest at the surface and at mid-depths, and flows northeast along the southern coast of the South Shetland Islands (Gordon \& Nowlin 1978, Gordon et al. 2000). Additional inflows of coastal water from the western Antarctic Peninsula through Gerlache Strait (GS) can enter into the BS from the southwest. The mixing and advection of these waters in the BS, coupled with the steep bathymetry and deep basins, create a cyclonic circulation within the BS that has a strong coastal boundary current on the north side and eddies over the basins (Zhou et al. 2002, 2006).

We adapted a survey design employed during austral summer to study the distribution and abundance of krill and predators during the austral winter, thereby providing direct comparisons of the spatial distribution, abundance, and biomass of krill over approximately $125000 \mathrm{~km}^{2}$ of the Southern Ocean. From 1996 to 2011, the US Antarctic Marine Living Resources (AMLR) Program annually conducted summer surveys (January-March) around the South Shetland Islands and sampled from a grid of up to 110 fixed stations allocated at 15-20 nautical mile (nmi) intervals once or twice each summer (Reiss et al. 2008). The survey area is divided into 4 strata: the west shelf stratum (WA), north of Livingston and King George Islands; the BS stratum, between the South Shetland Islands and the Antarctic Peninsula; the Elephant Island stratum (EI), an oceanographicallydynamic area and historic center of the summer krill fishery; and the coastal waters at the tip of the Antarctic Peninsula near JI.

Winter surveys were conducted aboard the research vessel/icebreaker (RVIB) 'Nathaniel B. Palmer' in August through September, 2012-2014. Winter stations were selected from the historic survey grid based on the amount of time available during the cruise and ice conditions (Fig. 1). During winter 2012 (August 1-17), a smaller number of stations was sampled owing to limited ship time. In that year, 37 stations were sampled mostly in the EI stratum, with some samples in the BS and JI strata. No samples were collected in the WA stratum. In 2013 (August 9 to September 8) and 2014 (August 19 to September 18), 88 and 114 stations were sampled throughout the South Shetland Islands area, respectively. During the 2 years (2012 and 2013) when ice was extensive, we sampled as far as $55 \mathrm{~km}$ into the ice in the JI and BS strata. In icefree areas offshore, we sampled most of the US AMLR survey stations during 2013, and in 2014, the lack of significant pack ice enabled us to sample the entire survey grid.

\section{Sea-ice concentration data}

Monthly sea-ice concentration data for June, July, and August of each year were extracted from the National Snow and Ice Data Center website (www. nsidc.org), and the sea-ice area $\left(\mathrm{km}^{2}\right)$ within the 15 and $50 \%$ ice concentration isopleths in each month was calculated for the area between $58^{\circ} \mathrm{S}$ and $48^{\circ} \mathrm{W}$, and $68^{\circ} \mathrm{S}$ and $65^{\circ} \mathrm{W}$ (see Figs. $2 \& 3$ ).

\section{Integrated chlorophyll a determination}

At each station, a conductivity, temperature, and depth (CTD) cast was made to within $10 \mathrm{~m}$ of the bottom or $750 \mathrm{~m}$ depth. The CTD, an SBE9/11 (SBE Inc.), was equipped with $10 \mathrm{l}$ bottles for water sampling, and bottles were closed on the upcast at 750, 200, $100,75,50,40,30,20,15$, and $5 \mathrm{~m}$. Chlorophyll a (chl a) concentrations were determined fluorometrically following Holm-Hansen et al. (1965). Integrated

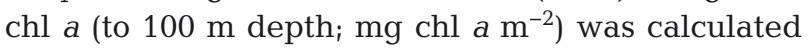
for each station (Reiss et al. 2009) and averaged for summer (15 yr) and winter (3 yr) surveys by survey stratum (EI, JI, BS, WA).

\section{Zooplankton sampling}

Krill and zooplankton were sampled using a $1.8 \mathrm{~m}$ (2.54 $\mathrm{m}^{2}$ mouth area) Isaacs-Kidd midwater trawl (IKMT) fitted with a $505 \mu \mathrm{m}$ mesh net. Volume filtered during trawls was determined using a calibrated General Oceanics flow meter (model 2030R) mounted on the depressor frame in front of the net. 


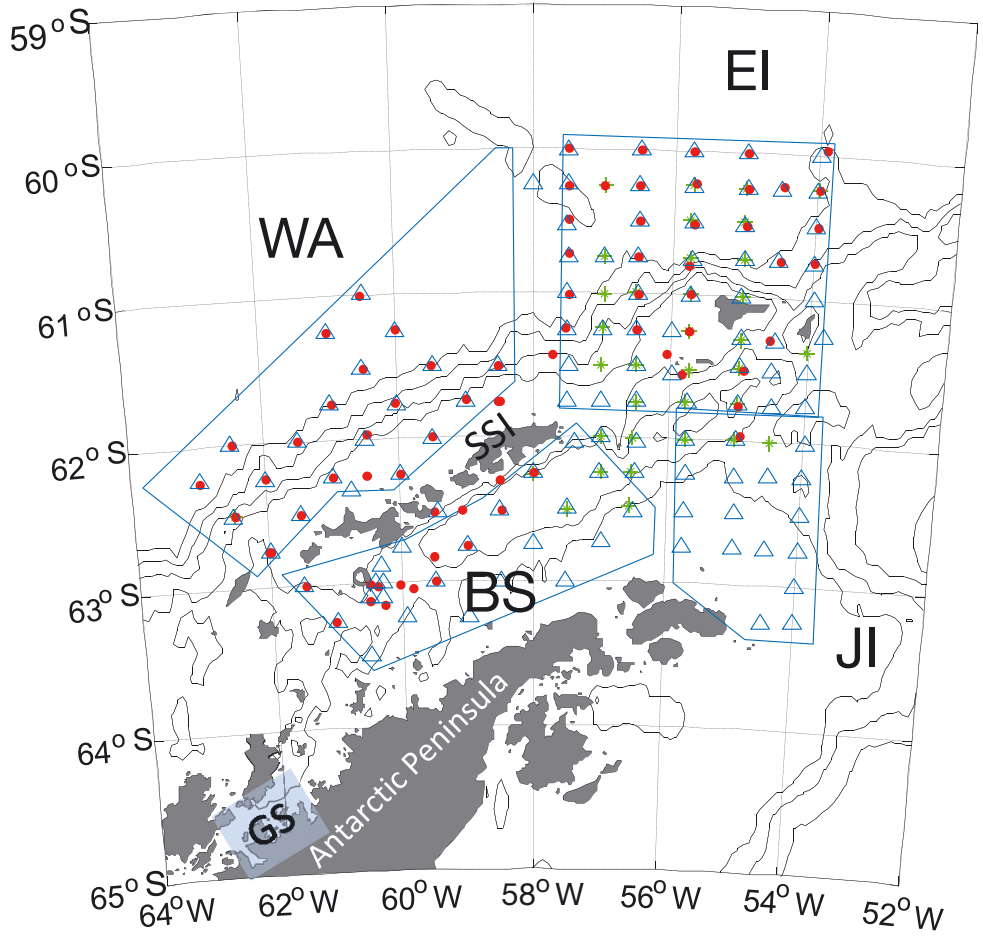

Fig. 1. Survey area, with sampling stations around South Shetland Islands (SSI) during winter $2012(*), 2013(\bullet)$, and $2014(\triangle)$. Areas outlined in boxes are areas in which Antarctic krill biomass estimates were made and include the west shelf (WA), Elephant Island (EI), Bransfield Strait (BS), and Joinville Island (JI) strata. Gerlache Strait (GS) is in the southwestern-most part of the map

All tows were double-oblique to $170 \mathrm{~m}$ or to ca. $10 \mathrm{~m}$ above bottom in shallower waters. Real-time tow depths were derived from a pressure sensor mounted on the trawl bridle. Tow speeds were $\sim 2$ knots, with volumes filtered averaging $\sim 3621 \mathrm{~m}^{3}$ (SE 21.16). Zooplankton abundance, including that of krill, was standardized to no. $\mathrm{m}^{-2}$ based on volume of water filtered multiplied by the depth of the tow.

\section{Krill measurement}

Immediately after each IKMT trawl, all zooplankton were sorted from the fresh samples. Krill were removed first, and a subsample of up to 100 postlarval krill was measured. Total body length (mm) was determined by measuring the distance from the tip of the rostrum to the posterior tip of the uropods (Standard 1 as described by Mauchline 1980). Lengthfrequency distributions for krill were derived for each stratum and season surveyed and used to convert the acoustic data into biomass.

\section{Acoustic data and biomass determination}

Acoustic data were collected in all years; however, acoustic data were only useful for estimating the biomass of krill in 2014, given the low ice concentrations and preponderance of open water in that year. A Simrad EK60 echosounder was used to collect acoustic data at 3 frequencies $(38,120$, and $200 \mathrm{kHz})$. All 3 frequencies were calibrated using the standard sphere technique (Foote 1990).

Krill were delineated from other acoustic scatterers using the 3-frequency stochastic distorted-wave Born approximation (SDWBA) model, using $95 \%$ of the total krill lengthfrequencies (measured from net tows) for each stratum to define dB-difference windows (Demer \& Conti 2005, Reiss et al. 2008, CCAMLR 2010). Only daytime acoustic data were used for biomass estimation to minimize potential bias caused by the diel vertical migration of krill (Demer \& Hewitt 1995). Acoustic data were processed using Echoview (ver. 4.9 ), with additional manual removal of noise created by ice scraping the hull. Data were integrated over the upper $250 \mathrm{~m}$ of the water column and into $1 \mathrm{nmi}$ bins. In general, where krill targets could be identified within the echogram but could not be isolated from the surrounding noise, those noisy data were excluded from the integration, thereby minimizing potential bias of including noise, but potentially biasing our biomass estimates downwards. Similarly, as we integrated the acoustic energy from $250 \mathrm{~m}$ to the surface, this approach would also exclude any biomass that was present deeper in the water column.

\section{Predator and sea-ice surveys}

Continuous observations of seabirds and marine mammals were conducted from the bridge (Santora 2014). Observations were collected simultaneously by 2 observers during daylight hours; one observer recorded all seabirds, while the other observer used $20 \times 60$ binoculars (20× magnification, $60 \mathrm{~mm}$ objective lens diameter) to scan for marine mammals. As ship survey speed varied according to sea-ice concentration and the icebreaker followed an irregular path through ice leads, predator observations and environmental data were binned into $1 \mathrm{nmi}$ intervals. In 2012, the sea ice was monitored during daylight hours, and scored on the percent cover, noting the 
general type of ice present. In 2013 and 2014, sea ice was continuously monitored during predator surveys and was classified according to a standardized seaice classification protocol (Scientific Committee on Antarctic Research [SCAR] Antarctic Sea Ice Processes and Climate [ASPeCt] program; Worby et al. 1999). Sea-ice conditions were logged automatically every $15 \mathrm{~s}$ and included estimates of percent ice coverage $(0-10$ scale, with 0 being open water and 10 being fully consolidated ice with no leads) and ice type (e.g. $1^{\text {st }}$ and $2^{\text {nd }}$ year, nilas, thin grey ice) (Worby et al. 1999, Worby \& Comiso 2004).

\section{Statistical analysis}

We examined stratum- and season-specific variability in krill abundance from net tows to assess if regional krill abundance varied from summer to winter. Our focus was on broad changes in the structure of the pelagic ecosystem and changes in krill and predator distribution patterns between summer and winter, not on the inter-annual variability in summer or winter abundance and distributions. We averaged krill abundance from net tows over the 15 summer surveys (1996-2011) and also for 3 winter surveys (2012-2014) among strata and used 2-way ANOVA to compare krill abundance and water-column phytoplankton biomass among strata (EI, WA, JI, SA) and between seasons (summer and winter). We tested the data for normality and applied various transformations. In general, however, all data from each factor could not be normalized using a single transformation. So we $\ln (x+1)$-transformed the data to reduce the variances between groups and use the 2 -way ANOVA acknowledging these limitations. We used Tukey-Kramer multiple comparisons to examine interactions and main effects. Alpha level $=0.05$.

Although summer and winter surveys were not consecutive, we assume the overall spatial pattern of krill abundance during past summers is comparable to the summers between winter surveys. Indeed, recent work (Siegel 2013) has shown that in the summer of 2013, krill distributions around the South Shetland Islands were similar to the pattern of distribution observed for the summer periods between 1996 and 2011, indicating that historical summer distributions are likely representative of patterns during the study period.

We used generalized additive models (GAMs) to assess the relationships between pinnipeds, sea-ice concentration, and integrated krill biomass. However, acoustic estimates of krill biomass were only available in 2014, so models were limited to this low-ice year. Counts of pinnipeds (crabeater seals Lobodon carcinophagus and Antarctic fur seals ArCtocephalus gazella), estimates of sea-ice concentration (percentage), and krill biomass were grouped into $1 \mathrm{nmi}$ intervals $(\mathrm{n}=629)$. The GAMs were specified as: Seal (count per nmi) $=s$ (sea-ice concentration $)+s($ krill biomass $)+t e($ Lon, Lat $)$, where $s$ is a smooth regression spline and te is a smoothed spatial interaction term between longitude and latitude. GAMs were implemented using the mgcv package in the R statistical program (R Development Core Team 2016), and we used generalized cross-validation to estimate smoothness parameters (Zuur et al. 2009). Adjusted pseudo- $\mathrm{R}^{2}$ and percent deviance explained were used to evaluate model performance.

\section{RESULTS}

\section{Sea-ice extent and distribution}

Sea-ice coverage in the study area varied among years and over the seasons (Figs. $2 \& 3$ ). In 2012, the area within the $15 \%$ concentration isopleth was $116132 \mathrm{~km}^{2}$ in June, increased slightly $\left(133377 \mathrm{~km}^{2}\right)$ in July, and then increased to more than $195000 \mathrm{~km}^{2}$ in August. The area within the $50 \%$ concentration isopleth ranged from 64 to $69 \%$ of that within the $15 \%$ sea-ice concentration isopleth during June and July 2012, declining to $47 \%$ by August as the ice extent continued to expand across the areas. In 2013, the $15 \%$ sea-ice area increased linearly from June to August, from 97310 to $341257 \mathrm{~km}^{2}$, respectively. At the same time, the $50 \%$ sea-ice area increased from 68368 to $226913 \mathrm{~km}^{2}$. In 2014, sea-ice extent was extremely variable; the area within the $15 \%$ sea-ice concentration isopleth declined between June and July, from 102027 to $100158 \mathrm{~km}^{2}$ in July, then increased to $218557 \mathrm{~km}^{2}$ in August. The area encompassed by the $50 \%$ sea-ice concentration isopleth followed a different trend. In June 2014, the $50 \%$ seaice concentration isopleth covered $70 \%$ of the area of the $15 \%$ isopleth. The $50 \%$ isopleth declined to $34 \%$ of the $15 \%$ sea-ice concentration area in July and August, indicating that most of the spatial coverage of ice consisted of loose and unconsolidated ice.

\section{Seasonal variability in water column productivity}

Depth-integrated chl a biomass varied significantly between summer and winter and among survey 


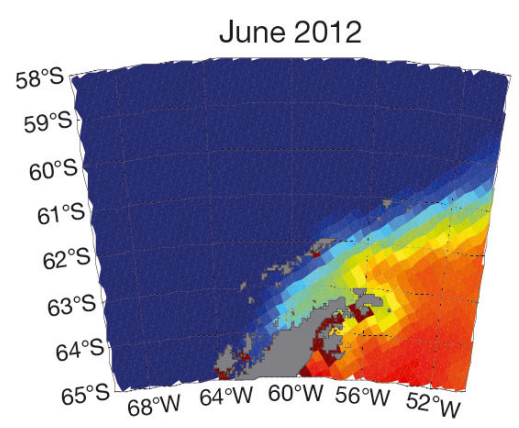

June 2013

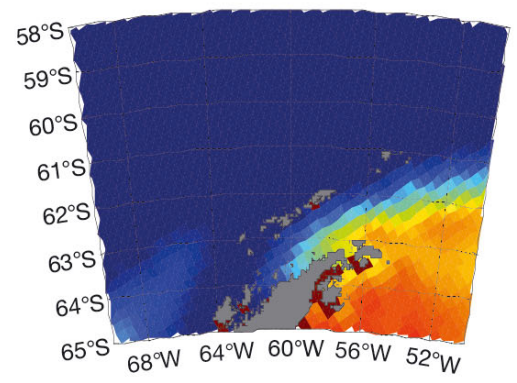

June 2014

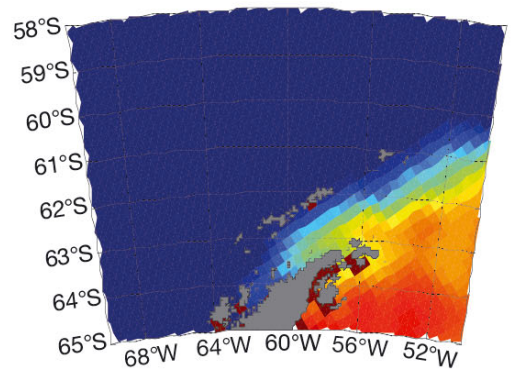

July 2012

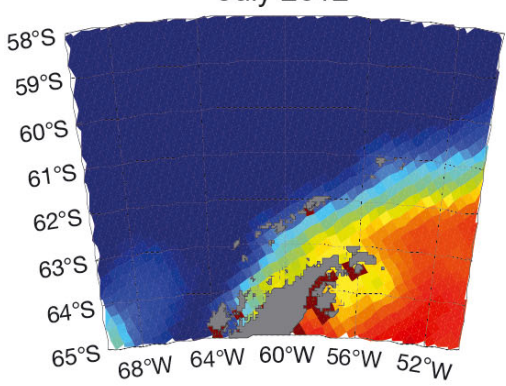

July 2013

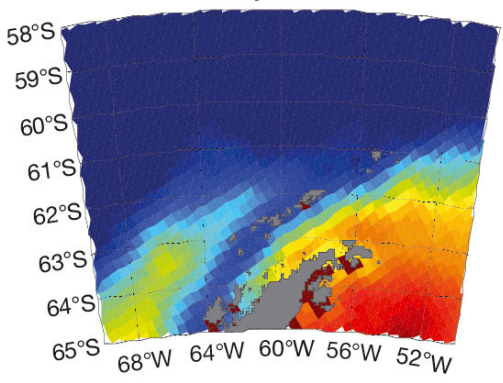

July 2014

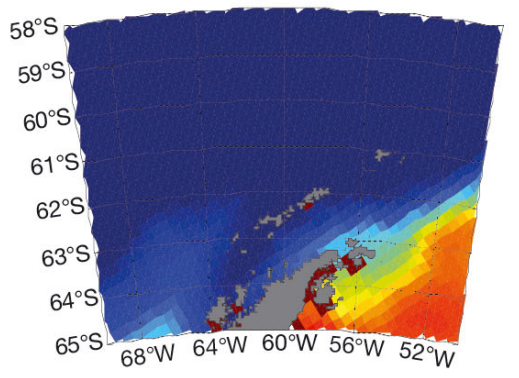

August 2012

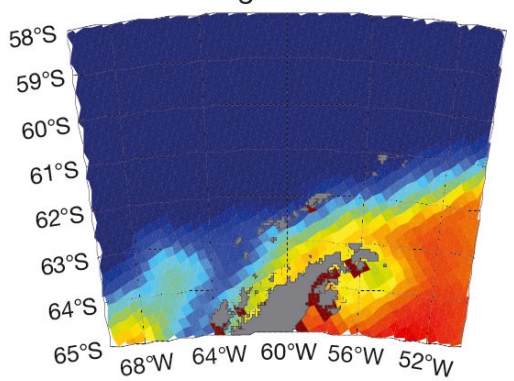

August 2013

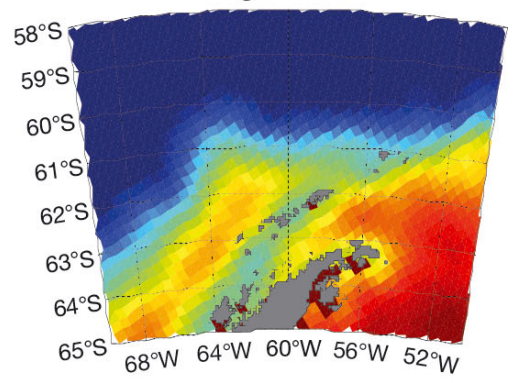

August 2014

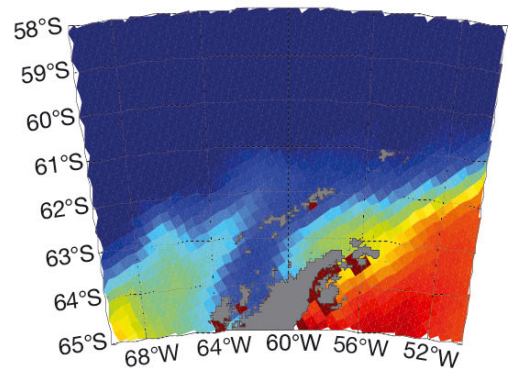

$$
\begin{array}{lllllllllll}
0 & 10 & 20 & 30 & 40 & 50 & 60 & 70 & 80 & 90 & 100
\end{array}
$$

Fig. 2. Maps of sea-ice concentration (percent cover) derived from data provided by National Snow and Ice Data Center (www.nsidc.org) satellite data for June, July, and August in 2012, 2013, and 2014, showing relative timing and development of sea-ice extent prior to oceanographic and acoustic surveys. Blue areas represent open water (no ice), while increasing red color indicates higher (up to $100 \%$; dark red) ice concentrations

strata but showed a similar pattern among winters (Fig. 4a). In winter, integrated chl a ranged from a low of $5.4 \mathrm{mg} \mathrm{m}^{-2}$ in BS during 2012 to a high of $18.4 \mathrm{mg} \mathrm{m}^{-2}$ in EI and WA during 2014. In general, the EI and WA had the highest integrated chl a biomass in winter, while BS and JI had consistently lower integrated chl a biomass. In summer, over the 15 yr time-series, the patterns were reversed; EI and WA strata had the lowest average chl a (54.85 and $41.8 \mathrm{mg} \mathrm{m}^{-2}$, respectively), while the JI and BS strata had higher integrated chl a biomass (58.9 and 68.4 $\mathrm{mg} \mathrm{m}^{-2}$, respectively) (Fig. 4a). Overall, integrated chl a biomass was 4.7 times greater in summer compared to winter. Results of a 2-way ANOVA (season and stratum as factors) showed a significant inter-

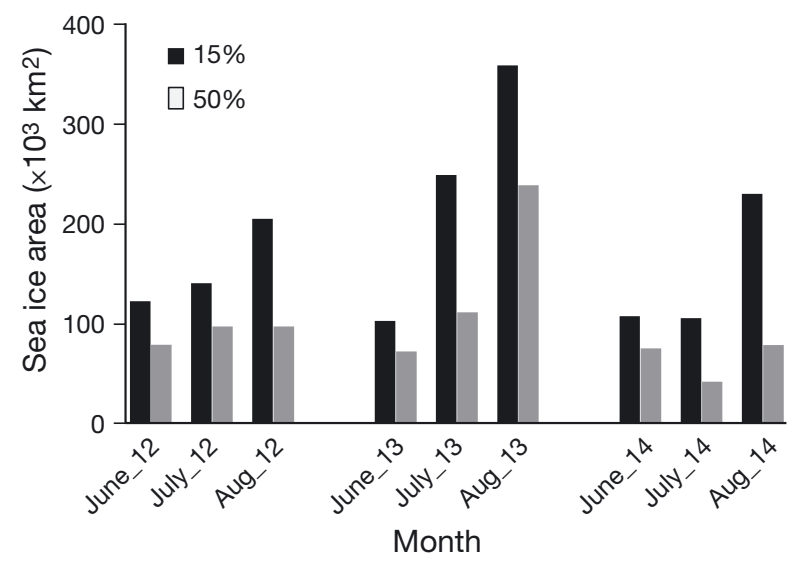

Fig. 3. Sea-ice area within 15 and $50 \%$ sea-ice concentration isopleths in June, July, and August of 2012, 2013, and 2014 around Antarctic Peninsula 
Table 1. Mean $( \pm \mathrm{SD})$ and median Antarctic krill abundance $\left(\right.$ no. $\mathrm{m}^{-2}$ ) from net tows across 4 sampling strata around Antarctic Peninsula between 15 summers and 3 winters. N: number of years surveyed between 1996 and 2014 (not all areas were sampled in all years); BS: Bransfield Strait; EI: Elephant Island; JI: Joinville Island; WA: west shelf

\begin{tabular}{|c|c|c|c|c|c|c|c|c|}
\hline \multirow{2}{*}{ Stratum } & \multirow[b]{2}{*}{$\mathrm{N}$} & \multirow[b]{2}{*}{$\begin{array}{l}\text { No. of } \\
\text { tows }\end{array}$} & \multirow{2}{*}{$\begin{array}{l}\text { Summer } \\
\text { Mean (SD) } \\
\text { krill abund. }\end{array}$} & \multirow[b]{2}{*}{$\begin{array}{c}\text { Median } \\
\text { krill abund. }\end{array}$} & \multirow[b]{2}{*}{$\mathrm{N}$} & \multirow[b]{2}{*}{$\begin{array}{l}\text { No. of } \\
\text { tows }\end{array}$} & \multirow{2}{*}{$\begin{array}{l}\text { - Winter } \\
\text { Mean (SD) } \\
\text { krill abund. }\end{array}$} & \multirow[b]{2}{*}{$\begin{array}{c}\text { Median } \\
\text { krill abund. }\end{array}$} \\
\hline & & & & & & & & \\
\hline EI & 15 & 1273 & $8.7(57.25)$ & 0.77 & 3 & 101 & $11.14(78.54)$ & 0.04 \\
\hline JI & 15 & 103 & $12.78(34.88)$ & 0.30 & 3 & 30 & $5.97(10.37)$ & 1.81 \\
\hline BS & 15 & 387 & 19.85 (92.38) & 0.25 & 3 & 43 & 305.34 (881.02) & 8.07 \\
\hline WA & 15 & 561 & $5.75(45.75)$ & 0.32 & 2 & 41 & $12.84(55.67)$ & 0.05 \\
\hline
\end{tabular}

action between season and stratum $\left(F_{(3,2451)}=14.8\right.$, $\mathrm{p}<0.0001)$, and significant difference between seasons $\left(F_{(1,2451)}=952.3, \mathrm{p}<0.00001\right)$ and also strata $\left(F_{(3,2451)}=5.01, \mathrm{p}<0.005\right)$. Therefore, while phytoplankton biomass was highest during summer as expected, the interaction indicates that the spatial distribution of chl a biomass differs between seasons, with relatively higher chl a biomass offshore within the ACC (EI and WA) strata and lower within the coastal BS and JI strata during winter.

\section{Seasonal changes in net-based krill abundance and distribution}

The spatial distribution and abundance of krill also changed between summer and winter (Table 1, Fig. 4b). Median abundances in the WA and EI strata during summer ranged between 0.32 and 0.77 krill $\mathrm{m}^{-2}$, respectively. During winter, median krill abundance in these 2 strata declined by an order of magnitude to $0.04 \mathrm{krill} \mathrm{m}^{-2}$ in the EI stratum during both winters, and to $0.05 \mathrm{krill} \mathrm{m}^{-2}$ in the WA stratum in 2014. In the JI stratum, median krill abundance during summer was $0.3 \mathrm{krill} \mathrm{m}^{-2}$, and ranged between 0.33 and $1.81 \mathrm{krill} \mathrm{m}^{-2}$ in winter 2013 and 2014, respectively. For the BS stratum during summer, median krill abundance was $0.25 \mathrm{krill} \mathrm{m}^{-2}$, and increased more than an order of magnitude to a median abundance of 8.07 krill $\mathrm{m}^{-2}$ during winter.

Results of a 2-way ANOVA (season and stratum as factors) on $\ln (x+1)$ krill abundance showed that krill were significantly more abundant in winter compared to summer (Fig. $4 \mathrm{~b}_{\text {; }}$ ANOVA, $\left.F_{(1,2648)}=9.19, \mathrm{p}<0.005\right)$, with a significant difference among strata $\left(F_{(3,2648)}=43.7, \mathrm{p}<0.0001\right)$. The significant interaction between season and stratum $\left(F_{(3,2648)}=44.8, \mathrm{p}<0.0001\right)$ further emphasizes the magnitude of the seasonal change in distribution from offshore spawning areas (WA and EI) during summer to coastal habitats in the JI and BS strata during winter.

\section{Distribution of acoustic krill biomass}

Acoustic estimates of krill biomass during summer among the 4 strata ranged almost an order of magnitude and showed considerable seasonal variability (Table 2, Fig. 5). Mean biomass density of krill during winter 2014 in the BS was $228 \mathrm{~g} \mathrm{~m}^{-2}$, an order of magnitude greater than the average biomass density for this stratum during summer. Additionally, this high biomass density was between 4 and 12 times greater than the biomass densities in the other strata during summer. Within the BS stratum, krill biomass ranged from 14695 metric tons (t) in summer 2005 to more than 1.6 million $t$ in summer 2011, and averaged 590000 t. In contrast, summer biomass in the WA and EI strata averaged 1.87 and 2.19 million $\mathrm{t}$, respectively.

Table 2. Mean biomass (millions of tons) and mean density $\left(\mathrm{g} \mathrm{m}^{-2}\right.$ ) of Antarctic krill in 3 strata around South Shetland Islands. Winter acoustic biomass estimates are from the single acoustic survey conducted in austral winter 2014 in the same strata. Coefficient of variation (CV) of survey biomass calculated using the Jolly \& Hampton (1990) method. N: number of years surveyed between 1996 and 2011 (not all areas were sampled in all years); BS: Bransfield Strait; EI: Elephant Island; WA: west shelf

\begin{tabular}{|c|c|c|c|c|c|c|}
\hline \multirow[t]{2}{*}{ Stratum } & \multicolumn{3}{|c|}{ - Summer } & \multirow[b]{2}{*}{$\mathrm{N}$} & \multicolumn{2}{|c|}{-Winter- } \\
\hline & $\mathrm{N}$ & $\begin{array}{l}\text { Mean }(\mathrm{CV}) \\
\text { krill biomass }\end{array}$ & $\begin{array}{l}\text { Mean krill } \\
\text { density }\end{array}$ & & $\begin{array}{l}\text { Mean }(\mathrm{CV}) \\
\text { krill biomass }\end{array}$ & $\begin{array}{c}\text { Mean krill } \\
\text { density }\end{array}$ \\
\hline EI & 15 & $2.19(27.5)$ & 55.9 & 1 & $0.076(51)$ & 1.7 \\
\hline WA & 15 & $1.87(49.5)$ & 51.6 & 1 & $0.211(76)$ & 5.5 \\
\hline BS & 15 & $0.47(37.8)$ & 26.8 & 1 & $5.500(54)$ & 228.5 \\
\hline
\end{tabular}




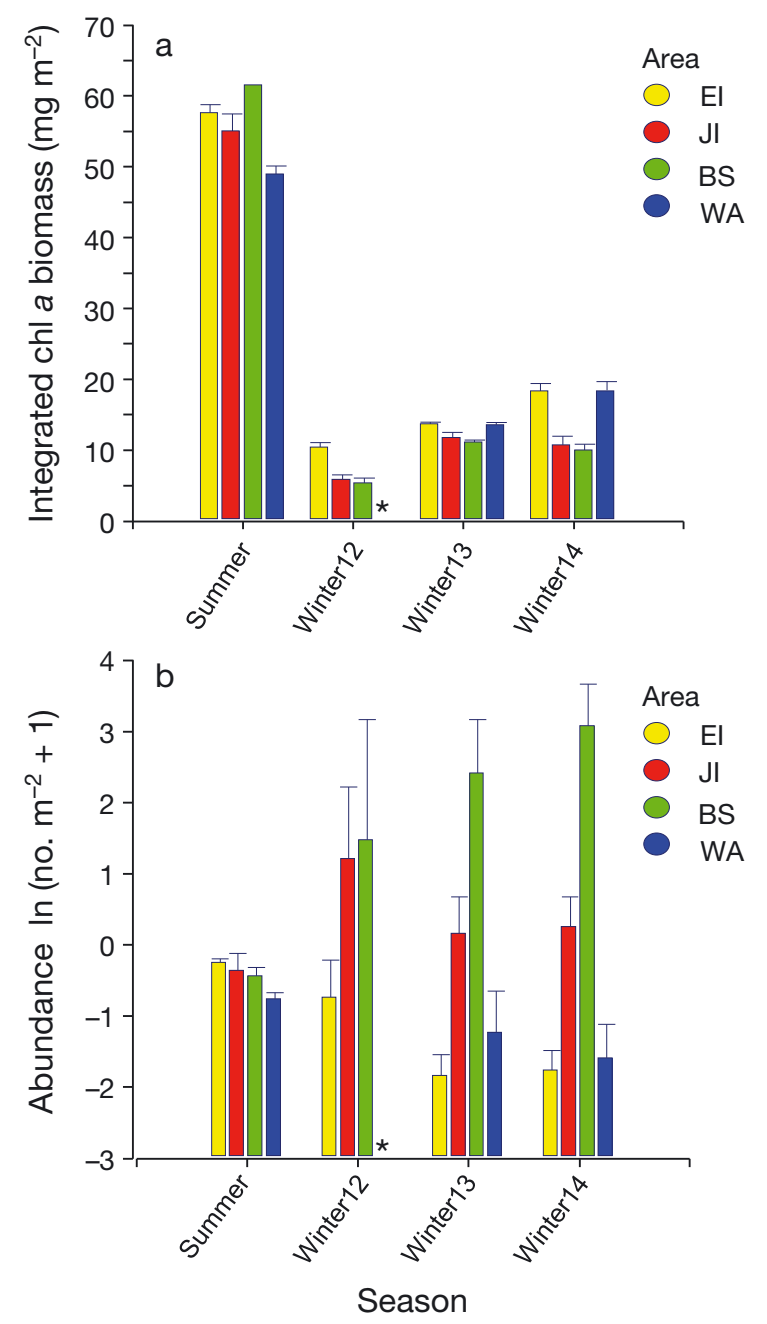

Fig. 4. (a) Average (+1 SE) integrated chl a biomass to $100 \mathrm{~m}$ depth from combined (1996 to 2011) summer and 3 winter surveys (2012, 2013, and 2014); (b) net-based Antarctic krill abundance (ln $\left(\right.$ no. $\left.\mathrm{m}^{-2}+1\right)$ ) averaged across 15 summers and 3 winter surveys among the 4 survey strata in the study area. Error bars are +1 SE. $*$ : area not sampled in 2012. BS: Bransfield Strait; EI: Elephant Island; JI: Joinville Island; WA: west shelf

During winter 2014, acoustic estimates of krill biomass in the WA and EI strata were much lower than summer estimates (200 000 and $76000 \mathrm{t}$, respectively). The acoustic estimate of krill biomass in the BS stratum during winter 2014 was 5.5 million $\mathrm{t}$, about 3.5 times the maximum summer biomass, and nearly an order of magnitude greater than the average summer biomass recorded for this stratum (Table 2, Fig. 5). In fact, the biomass in BS $(20 \%$ of the survey area) represented about $92 \%$ of the average total summer biomass for the entire US AMLR study area, and $8 \%$ of the standing stock of the southwestern Atlantic estimated during summer 2000 (Hewitt et al. 2004, CCAMLR 2010).

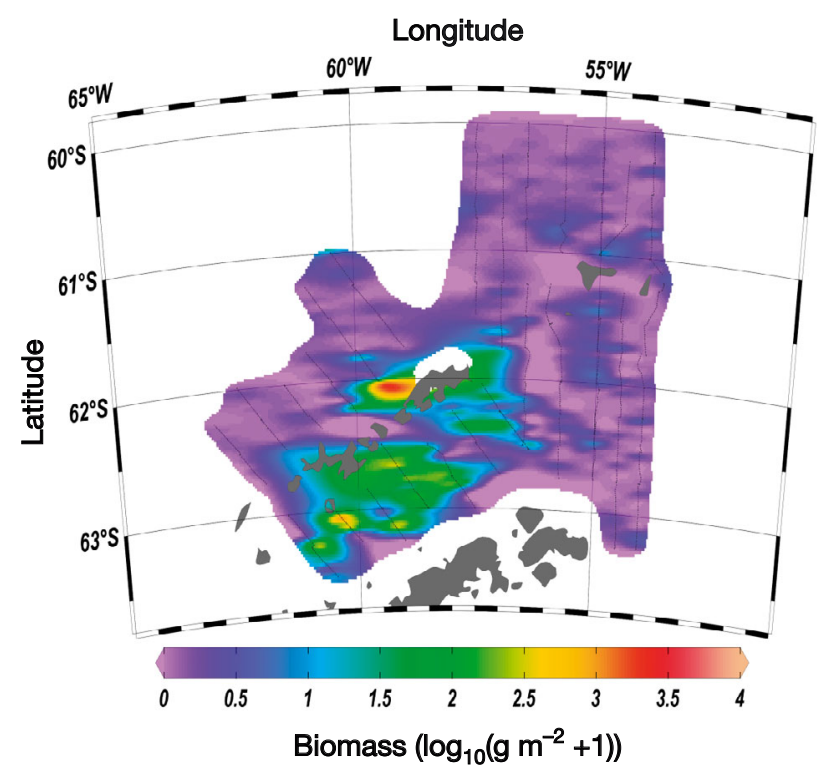

Fig. 5. Distribution of acoustically derived Antarctic krill (Euphausia superba) biomass $\left(\log _{10}\left(\mathrm{~g} \mathrm{~m}^{-2}\right)\right)$, estimated using 3-frequency stochastic distorted-wave Born approximation (SDWBA; CCAMLR 2010) across South Shetland Islands during winter 2014

\section{Pinniped distribution and relationship to sea ice and krill biomass}

The spatial distributions and relative abundances of crabeater and Antarctic fur seals further emphasize the importance of the seasonal shift in krill distribution into the BS during winter (Fig. 6). Regardless of year, crabeater seals were almost entirely associated with high krill biomass areas within BS during winter (Figs. $5 \& 6 a, b)$. Crabeater seals were virtually absent from areas with low sea-ice concentrations like the WA or EI strata, but were also absent from the JI stratum where first-year ice occurred but krill biomass was low. The relative abundance of crabeater seals peaked when sea-ice concentration was greater than $70 \%$ within BS (Fig. 6c,d). In comparison, in both years, Antarctic fur seals (Fig. 6a,b) were more broadly distributed than crabeater seals, and occurred throughout the survey area, including in areas with low to moderate seaice concentrations (e.g. 20 to $40 \%$; Fig. 6c,d). Both crabeater and Antarctic fur seals were more abundant in 2014 than 2013 (Mann-Whitney $U, \mathrm{p}<$ 0.001), with larger aggregations of animals (repeated sightings of 150 to 400 ind. $\mathrm{nmi}^{-1}$ ) concentrated on the lower number of ice floes suitable for hauling out in 2014. The GAMs performed better for 
a

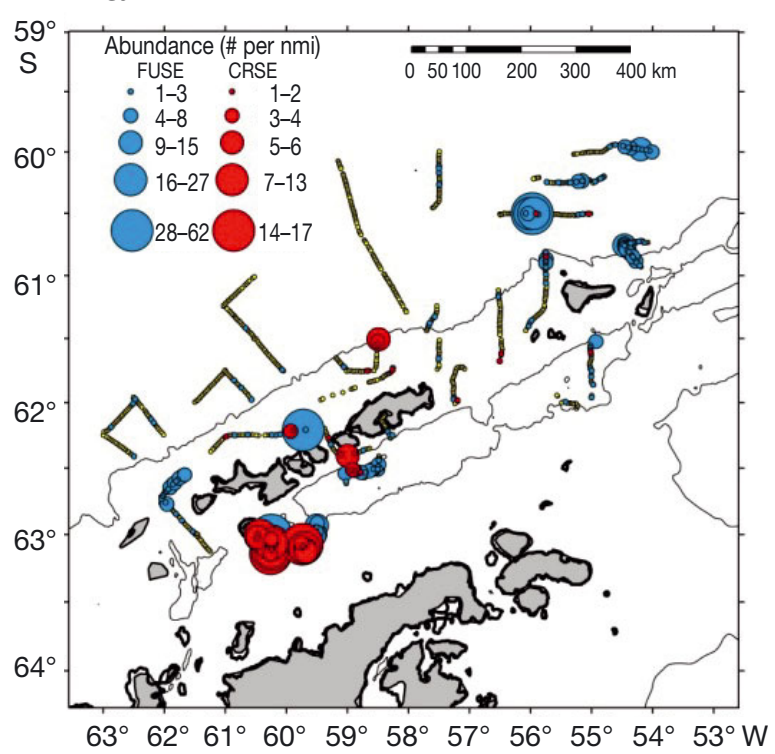

$63^{\circ} 62^{\circ} 61^{\circ} 60^{\circ} 59^{\circ} 58^{\circ} 57^{\circ} 56^{\circ} 55^{\circ} 54^{\circ} 53^{\circ} \mathrm{W}$

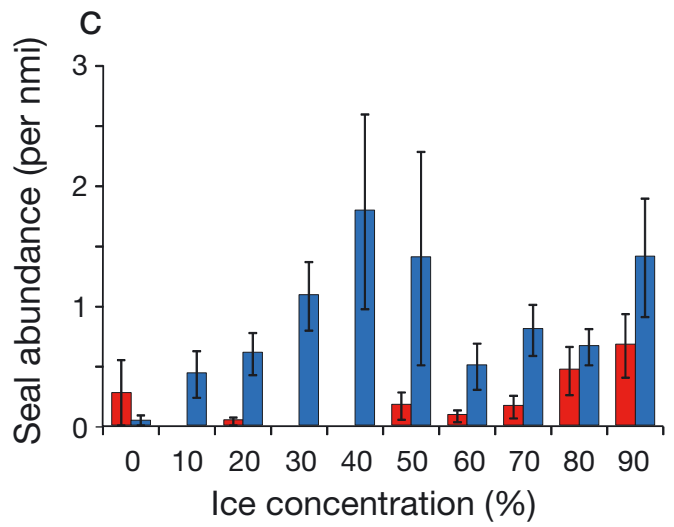

b
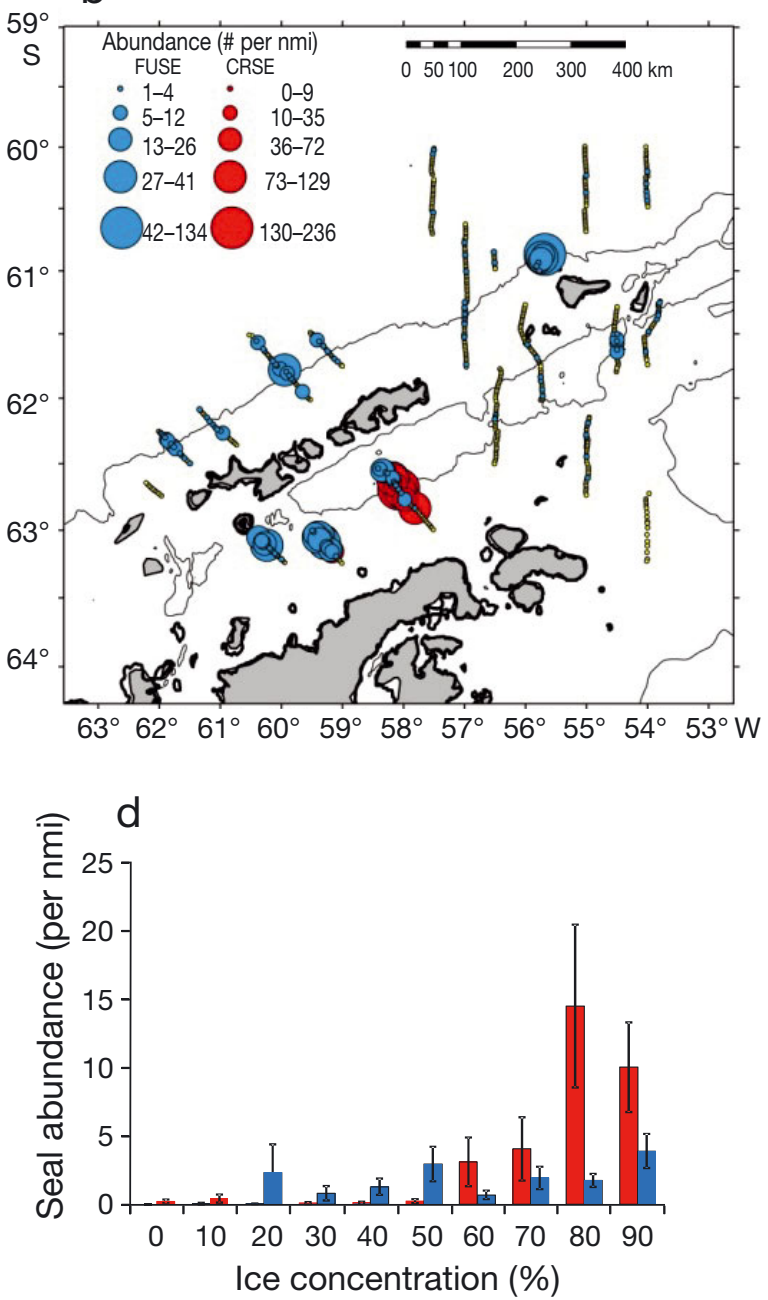

Fig. 6. Relative abundance (ind. $\mathrm{nmi}^{-1}$ ) of crabeater seals (CRSE; red circles) and Antarctic fur seals (FUSE; blue circles) in the study area during winter (a) 2013 and (b) 2014. Note difference in scales. Average relative abundance (ind. nmi $\left.{ }^{-1}\right)( \pm 1$ SD) of crabeater (red bars) and Antarctic fur seals (blue bars) by ice concentration (\%) during daytime visual surveys along acoustic transect during (c) 2013 and (d) 2014

Table 3. Results of generalized additive models for assessing spatial distribution pattern and response of crabeater seals and Antarctic fur seals to sea-ice concentration and Antarctic krill biomass; te(Lon, Lat) is spatial component that includes a smoothed interaction term between longitude and latitude. Edf: estimated degrees of freedom, Res.df: residual degrees of freedom, \%Dev: percent deviance explained. $\mathrm{R}^{2}=$ adjusted pseudo- $\mathrm{R}^{2}$

\begin{tabular}{|lrrrcrc|}
\hline & Edf & Res.df & \multicolumn{1}{c}{$F$} & $\mathrm{p}$ & $\%$ Dev & $\mathrm{R}^{2}$ \\
\hline Crabeater seal & & & & & 88.2 & 0.71 \\
Sea ice & 2.49 & 2.81 & 16.45 & $<0.0001$ & & \\
Krill biomass & 2.98 & 2.99 & 67.26 & $<0.0001$ & & \\
$t e($ Lon, Lat) & 13.94 & 15.06 & 7.35 & $<0.001$ & & \\
Antarctic fur seal & & & & & 58.3 & 0.31 \\
Sea ice & 2.75 & 2.95 & 12.50 & $<0.0001$ & & \\
Krill biomass & 2.21 & 2.56 & 28.75 & $<0.0001$ & & \\
te(Lon, Lat) & 22.08 & 22.79 & 17.34 & $<0.0001$ & & \\
\hline
\end{tabular}

crabeater than for Antarctic fur seals (percent deviance explained was 88 and $58 \%$, respectively), which we attributed to the broader distribution of fur seals across a variety of sea-ice habitats (Table 3, Figs. 6 \& 7). GAMs indicated that crabeater and fur seals were positively related to sea-ice concentration and krill biomass during 2014, but displayed different functional relationships (Fig. 7). The GAM for crabeater seal abundance showed a threshold response to sea-ice concentration, and high abundance of crabeater seals was always associated with high krill biomass. In contrast, the GAM for fur seals indicates they used a variety of sea-ice concentrations, and their abundance increased monotonically with krill biomass. 

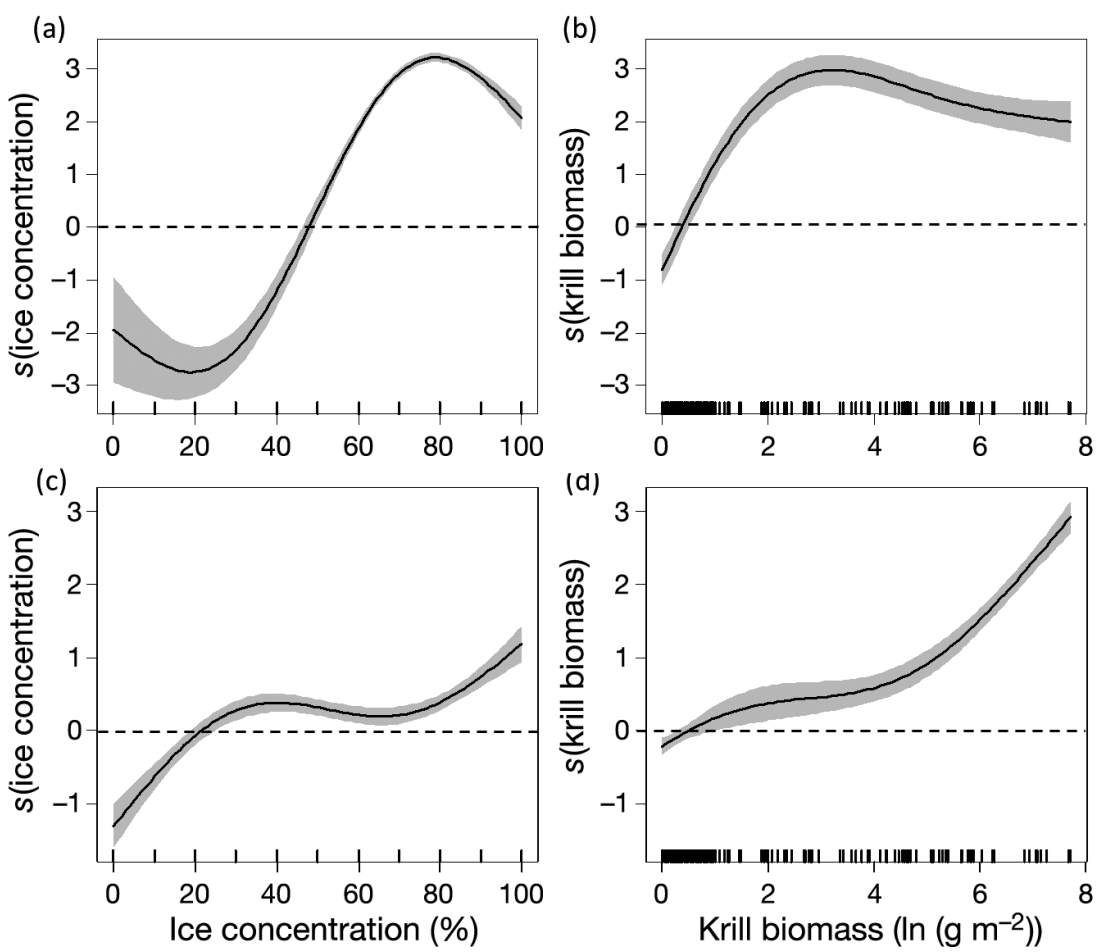

Fig. 7. Results of generalized additive models for assessing functional relationships between $(a, b)$ crabeater seals or $(c, d)$ Antarctic fur seals and $(a, c)$ sea-ice concentration $(\%)$ and $(\mathrm{b}, \mathrm{d})$ Antarctic krill biomass $\left(\ln \left(\mathrm{g} \mathrm{m}^{-2}\right)\right)$ during 2014. Shaded areas indicate $95 \%$ CIs, and ticks above $x$-axis indicate data availability (note sea-ice concentration is recorded in tenths; see Fig. 6)

\section{DISCUSSION}

\section{Krill biomass in winter and summer}

There is considerable discussion in the literature (Siegel 1988, Lascara et al. 1999, Siegel et al. 2013, Cleary et al. 2016) regarding the importance of the seasonal shoreward migration of krill to coastal waters. Yet, there is less information on the magnitude of this difference and the resulting changes in ecosystem structure (Atkinson et al. 2008). Our data show that the coastal waters of the BS have been an important overwinter habitat for krill within the northern Antarctic Peninsula ecosystem. Krill biomass in the BS increased by more than an order of magnitude between summer and winter, while offshore areas have a similar biomass decline. These findings support the seasonal shoreward migration hypothesis (Siegel 1988, 1989). This order of magnitude seasonal change in distribution and biomass occurs regardless of the concurrent sea-ice conditions (i.e. concentration and area). This spatial re-organization in winter krill biomass has major consequences for understanding the ecology of krill, inferring the impacts of climate change on krill habitat during winter, trophic interactions, and fisheries management.

The use of acoustics in winter is often limited by the presence of ice. As the ship moves through even thin ice, the noise of the ice against the hull contaminates the acoustic returns that might be attributed to krill and other scatterers. This was the case in 2012 and 2013, when the ship routinely broke solid ice, obviating the ability to derive areal estimates of krill biomass in most areas in those years. However, estimates of krill biomass in ice-free areas in both 2012 and 2013 were also very low $\left(\sim 1 \mathrm{~g} \mathrm{~m}^{-2}\right.$; US AMLR Program unpubl. data). In contrast, during 2014, the ice concentration and distribution were sufficiently low that the entire northern Antarctic Peninsula was sampled, and high-quality acoustic data were collected throughout (Fig. $6)$. The lack of ice meant that there was little physical habitat for the development of ice-algal communities that are often hypothesized to be critical to overwinter survival (Meyer 2012). This observation is strong evidence that the concentration of krill post-larvae in the BS was independent of sea ice or its algal community in 2014.

In contrast to the noise that limits the use of acoustics to largely ice-free areas and winters, nets were deployed regardless of the ice concentration and estimates of krill abundance from net tows were made in each stratum in all years. The ability to tow the nets in the wake of the ship regardless of ice thickness also meant that net-based abundance estimates of krill could be used to corroborate the overall pattern of krill abundance and distribution in the high- (2012 and 2013) and low- (2014) ice years. Over the 3 winters, net-based krill densities were more than an order of magnitude higher within the BS and JI strata compared to summer and showed that krill were much less abundant in WA and EI strata (Fig. 4b) during winter compared to summer. Although net-based krill densities are often underestimates of the true density of krill in a sample, owing to net avoidance and vertical migration of krill below the maximum tow depth during daytime (a significantly reduced problem in winter when daylight is just 6-8 h compared to summer), the overall spatial patterns of relative krill abundance and biomass are 
retained (Siegel 2005). So we think that the patterns of abundance derived from net samples reflect the consistent use of the BS by krill in winter regardless of ice, while the biomass estimate in 2014 quantifies the magnitude of that biomass.

The spatio-temporal development of sea-ice extent is important for both larval and juvenile overwintering krill; sea ice provides habitat for krill to escape predators, a solid substrate that minimizes advective loss, and food in the form of sea-ice algal and microbial communities (Daly 1990, 1998, Flores et al. 2012b, Meyer 2012). Furthermore, krill post-larvae cannot survive winter without feeding (Meyer 2012), and while post-larvae may not require the sea ice to avoid advective loss, the productivity of sea-ice communities may enhance krill survival and future production, as winter conditions can impact krill body condition the following summer (Reiss et al. 2014). Yet, we found little evidence that during winter, krill were concentrated in areas of higher primary production (e.g. offshore in the ACC, or in the WA stratum) where chl a biomass was high. Krill were also not constrained only to areas with high sea-ice concentrations. Instead, krill were concentrated in the BS regardless of the physical or biological conditions we observed. The flexibility of krill diets may explain this apparent independence (Schmidt et al. 2014) despite the need to feed during winter (Meyer 2012). Benthic feeding, cannibalism, and omnivorous feeding are all likely possibilities (Schmidt et al. 2011, 2014). Indeed, krill were observed to vertically migrate within the BS between night and day, and were observed on the bottom as deep as $500 \mathrm{~m}$ at times (US AMLR Program unpubl. data). Yet, the fact that over 5 million $t$ were present suggests that our understanding of krill overwinter survival strategies is still very limited.

In the BS, the order of magnitude increase in biomass observed in winter must have resulted from active horizontal migration from offshore feeding and spawning areas occupied during summer, rather than by passive transport by currents from those areas. This is because the circulation patterns are largely controlled by the bathymetric contours of the region, and seasonal differences in the strength of currents are not substantially different (Savidge \& Amft 2009, Jiang et al. 2013). It is known that hydrographic features can affect the distribution of krill at macro(1000s km; Nicol et al. 2000) and meso-scales (10s to 100s km; Allen et al. 2001, Simard \& Lavoie 1999, Santora et al. 2012), and can result in consistently high krill concentrations if krill behavior also contributes. At fine scales, behavior, such as diel vertical migration, is also known to exert strong control on the formation of krill aggregations (Dorman et al. 2015), and it is generally agreed that aggregation and accumulation of krill and zooplankton may result from interactions among bathymetry, circulation, and behavior (e.g. diel vertical migration, swarming, and the need to continually swim) (Simard \& Lavoie 1999, Allen et al. 2001, Cotté \& Simard 2005, Santora \& Reiss 2011). However, it is clear from the magnitude of the biomass accumulation in the BS that krill behavior (which can change seasonally) is responsible for the accumulation of krill in this region. While sea ice is often regarded as an important component of krill habitat, less emphasis has been placed on understanding other physical features of the environment that could provide organizational cues for krill aggregating over winter.

Acoustic biomass densities observed within the BS during winter 2014 averaged $228 \mathrm{~g} \mathrm{~m}^{-2}$, much higher than any biomass density observed during summer in this region (Cossio \& Reiss 2007, Reiss et al. 2008), and higher than elsewhere along the peninsula where acoustic measurements have been made during autumn or winter. For example, Lawson et al. $(2008 \mathrm{a}, \mathrm{b})$ reported that during the Southern Ocean Global Ocean Ecosystem Dynamics (GLOBEC) program, acoustic biomass ranged from 1.3 to $77 \mathrm{~g} \mathrm{~m}^{-2}$ and was greatest below $100 \mathrm{~m}$ in Marguerite Bay during autumn and winter 2001 and 2002, and that krill were also found on the bottom ( 500 m). This pattern of acoustic biomass density (higher concentrations nearshore) indicates that Marguerite Bay is an important coastal overwintering area. In the BS, krill density was concentrated in the upper $200 \mathrm{~m}$, although krill were visible on the 38 and $120 \mathrm{kHz}$ echosounders down to $500 \mathrm{~m}$.

Our acoustic estimates of krill biomass are likely underestimates because the signal to noise ratio of the $200 \mathrm{kHz}$ echosounder limits the integration depth to $250 \mathrm{~m}$. Despite the potential limitation of integrating over just $250 \mathrm{~m}$, our estimates of krill biomass are substantially higher than the biomass observed in Marguerite Bay, and the krill were concentrated in the water column, further highlighting the importance of the basins in the BS in winter. Overall, it is clear that other areas (e.g. Marguerite Bay, and the straits and passages around islands along the peninsula) with similar hydrographic features that might concentrate krill near the coast during winter are important and, with decreasing sea ice due to climate change, such areas may become accessible and subject to higher exploitation rates by the krill fishery in the future. 


\section{Sea ice, krill, and predators}

Climate-induced variability in sea-ice extent, duration, and composition (size and floe types) will impact upper trophic level predators in polar ecosystems (Siniff et al. 2008, Forcada et al. 2012). For example, sea ice provides important foraging habitat for krilldependent predators, and is required by some predators to haul out and reproduce (Ribic et al. 1991, Siniff et al. 2008). Our data suggest that crabeater seal habitat is associated with sea-ice concentrations greater than $70 \%$, while Antarctic fur seals were associated with a broader range of sea-ice conditions. However, both species were clearly associated with areas of increased krill biomass, indicating they are closely linked to the krill biomass during winter. Crabeater seals are ice-dependent and must therefore find areas of reliable prey concentration associated with pack ice or in the vicinity of polynyas and other oceanographic features that concentrate krill and predators alike (Burns et al. 2004, 2008). The consistent overlap between crabeater seals and krill biomass within coastal waters of the BS indicates that further research with respect to the sensitivity of crabeater seals to changes in winter sea-ice conditions and potential interactions with the krill fishery is warranted (Siniff et al. 2008).

The at-sea abundance of Antarctic fur seals in our study area increases by an order of magnitude from summer to early autumn (Santora 2013), and the high abundances reported in the present study indicate this region is an important overwintering area (Santora 2014). Likewise, the relatively high abundance of Antarctic fur seals, composed of sub-adult and adult males (J. Santora pers. obs.) within the BS, indicates this species is using the same krill biomass hotspots as crabeater seals. Estimates of krill consumption by Antarctic fur seals rely on summer monitoring data (Hill et al. 2007), yet the large numbers of these predators and concentrated food resources in the BS during winter suggest that this area may be important for understanding trophodynamics and population-wide consumption estimates.

Future declines in winter sea-ice conditions may impact ice-dependent seals, especially if sea-ice extent, duration, or concentrations decrease in areas where krill biomass is concentrated. Our observations indicate a significant increase in both species during 2014 when sea ice was less prevalent and floes were smaller, suggesting that haul-out habitat in krill-rich areas could be limited. Additionally, there is a potential for increased predation by killer whales Orcinus orca on crabeater seals during these low-ice years as killer whales gain greater access to areas where flows may be smaller, potentially making hunting easier. Moreover, in years with less sea ice, the potential interaction between the krill fishery and seals may be intensified as the seals are constrained to smaller or more fragmented ice habitat within areas where the fishery may focus future effort (Nicol \& Foster 2016).

\section{Climate and management implications}

The response of the Southern Ocean to global climate change and warming is projected to result in changes throughout the physical and biological components of the ecosystem (Constable et al. 2014, Gutt et al. 2015). The Intergovernmental Panel on Climate Change (IPCC) projects that physical changes owing to increasing water and air temperatures over the next 85 yr (IPCC 2007) will continue to accelerate and broaden changes in ecosystem structure and function (Gutt et al. 2015). Thus, there is considerable interest in projecting the impacts of climate change over the long term. For example, habitat models built from climate change projections indicate shifts in spatial habitat for krill by 2100 because of changing water temperature and primary production (Hill et al. 2013), changes in larval production (Piñones \& Fedorov 2016), impacts on larval survival as pH declines (Kawaguchi et al. 2013), and changes in the distribution of sea ice and coincident larval habitat (Melbourne-Thomas et al. 2016) emphasizing the importance of long-term effects. However, over the last 30 to $50 \mathrm{yr}$, climate-related changes in the primary atmospheric climate mode, the Southern Annular Mode (SAM), have strengthened the warm westerly winds and driven declines in sea-ice extent and duration around the Antarctic Peninsula (Stammerjohn et al. 2008b, Yuan \& Li. 2008). As a result, annual sea-ice duration has declined by more than $90 \mathrm{~d}$, with later ice formation and earlier melting. Thus, contemporary climate-induced changes will have more immediate ecological and management consequences before longer-term outcomes may come to fruition.

The declines in sea-ice extent and duration within the Antarctic Peninsula ecosystem will potentially increase access by the krill fishery to areas that were historically ice-covered, requiring appropriate management actions. As part of the Commission for the Conservation of Antarctic Marine Living Resources (CCAMLR) Ecosystem Monitoring Program (CEMP), risks to krill-dependent predators from fishing ac- 
tivity are largely evaluated based on demographic monitoring studies conducted during the austral summer, when land-based predators (e.g. penguins and pinnipeds) are reproductively active (Agnew 1997, Siniff et al. 2008). Comparatively less monitoring of predator populations has occurred during postbreeding periods, especially in winter. Many species that are monitored within the CEMP undergo latesummer migrations to overwinter in other areas of the Antarctic or sub-Antarctic (Stevick et al. 2004, Lea et al. 2008, Hinke et al. 2015). It was assumed that spatial overlap and negative interactions between these krill predators and the fishery were minimal during winter in the Antarctic Peninsula. The data here show a substantial abundance of pinnipeds, including Antarctic fur seals, which are monitored within the CEMP, and crabeater seals (an unmonitored species), coincident with regionally-confined, dense, krill aggregations in the BS. Recent tagging data on a number of krill predators (penguins and pinnipeds; Hinke et al. 2017; https://swfsc.noaa.gov/ AntarcticPredators/) also show that the BS is an important habitat during winter. This enormously concentrated and predictable food source provides a simple answer for the importance of this area to these predators.

Over the last decade, the krill fishery has increased its catch, shifted its main period of fishing from midsummer towards autumn and winter (in part owing to open water during autumn), and has become more spatio-temporally concentrated (CCAMLR 2014, Nicol \& Foster 2016). In 2009, CCAMLR instituted interim catch limits for this area (Food and Agriculture Organization of the United Nations [FAO] Subarea 48.1; $155000 \mathrm{t}$ ). Much of the catch has recently been taken in the BS, and in some years the fishery has operated into August. More recently, catch limits have been reached by mid-April and mid-May, resulting in early closures of the krill fishery in Subarea 48.1 in those years (Nicol et al. 2012). While the current catch is low relative to the estimated regional biomass for this area during winter (Table 2), there is considerable interest in expanding the fishery above the current $155000 \mathrm{t}$ limit within this area, which would allow continued fishing into winter. Thus, new data are needed to understand the potential effects of high local exploitation rates in winter, in addition to effects of the larger overall catch limits.

The current catch limits for krill apply to areas (e.g. all of Subarea 48.1) that are much larger than the area of the BS (CCAMLR 2014). It is unclear whether the current local exploitation rates within the BS increase the risk to meeting the objectives in Article
II of the Convention on the Conservation of Antarctic Marine Living Resources, which requires that fishing impacts be reversible within 20 to $30 \mathrm{yr}$ and that impacts on krill-dependent and associated predators be considered. Developing strategies to mitigate the increased risk to krill populations and their dependent predators in the face of changing ecosystem structure will likely require monitoring the winter distribution of krill and krill predators (Hinke et al. 2017), examining the effects of climate change over both the short and long term, and developing harvest-control rules to ensure the krill fishery is managed in an ecosystem-based context.

\section{CONCLUSIONS}

Here we have been able to capitalize on the fact that sea-ice extent and duration have declined and revealed the magnitude of the seasonal redistribution of krill from offshore to onshore, the location of a major krill overwintering ground, and the link to winter-habitat use for upper trophic level predators in the northern Antarctic Peninsula region. Yet, as climate change continues around the Southern Ocean, the structure of its pelagic ecosystems will change (Schofield et al. 2010). Over the long term, projected effects on the pelagic environment will include changes to krill habitat (Hill et al. 2013, MelbourneThomas et al. 2016) and krill productivity (Kawaguchi et al. 2013), suggesting the potential for a longterm change to the functional links within the Southern Ocean. Understanding the details of these changes will require studies throughout the ecosystem (Smetacek \& Nicol 2005), including across seasons. Winter studies, especially studies that focus on the transition from winter to spring, are critically important to developing a better and more quantitative understanding of the structure and function of the Southern Ocean ecosystem. Such studies are also important to develop effective, precautionary management strategies that can allow for the rational development of the krill fishery while protecting krill-dependent predators.

Acknowledgements. We thank the crew and science support personnel of the RVIB 'Nathaniel B. Palmer' for all their help. We also thank our technicians for the long hours and enthusiasm collecting and processing the samples at sea. This paper derived from a discussion paper presented at the CCAMLR Working Group for Ecosystem Monitoring and Management. We thank the National Science Foundation for the collaboration to use the RVIB 'Nathaniel B. Palmer' for this study. 


\section{LITERATURE CITED}

Agnew DJ (1997) Review: the CCAMLR ecosystem monitoring programme. Antarct Sci 9:235-242

Allen SE, Vindeirinho C, Thomson RE, Foreman MG, Mackas DL (2001) Physical and biological processes over a submarine canyon during an upwelling event. Can J Fish Aquat Sci 58:671-684

Atkinson A, Siegel V, Pakhomov E, Rothery P (2004) Longterm decline in krill stock and increase in salps within the Southern Ocean. Nature 432:100-103

Atkinson A, Siegel V, Pakhomov EA, Rothery P and others (2008) Oceanic circumpolar habitats of Antarctic krill. Mar Ecol Prog Ser 362:1-23

Atkinson A, Siegel V, Pakhomov EA, Jessopp MJ, Loeb V (2009) A re-appraisal of the total biomass and annual production of Antarctic krill. Deep-Sea Res I 56:727-740

Burns JM, Costa DP, Fedak MA, Hindell MA and others (2004) Winter habitat use and foraging behavior of crabeater seals along the Western Antarctic Peninsula. Deep-Sea Res II 51:2279-2304

Burns JM, Hindell MA, Bradshaw CJA, Costa DP (2008) Fine-scale habitat selection of crabeater seals as determined by diving behavior. Deep-Sea Res II 55:500-514

CCAMLR (Commission for the Conservation of Antarctic Marine Living Resources) (2010) Report of the fifth meeting of the Subgroup on Acoustic Survey and Analysis Methods. Rep No. SC-CCAMLR-XXIX/6. CCAMLR, Hobart

CCAMLR (2014) Draft krill fishery report. Rep No. WG-EMM14/58. Commission for the Conservation of Antarctic Marine Living Resources (CCAMLR), Hobart

* Cleary AC, Durbin EG, Casas MC, Zhou M (2016) Winter distribution and size structure of Antarctic krill Euphausia superba populations in-shore along the West Antarctic Peninsula. Mar Ecol Prog Ser 552:115-129

* Constable AJ, Melbourne-Thomas J, Corney SP, Arrigo KR and others (2014) Climate change and Southern Ocean ecosystems I: how changes in physical habitats directly affect marine biota. Glob Change Biol 20:3004-3025

Cossio AM, Reiss C (2007) Krill biomass update of the South Shetland and Elephant Island regions of Area 48. Rep No. WG-EMM-07/31. Commission for the Conservation of Antarctic Marine Living Resources (CCAMLR), Hobart

Cotté C, Simard Y (2005) Formation of dense krill patches under tidal forcing at whale feeding hot spots in the St. Lawrence Estuary. Mar Ecol Prog Ser 288:199-210

Croll DA, Tershy BR (1998) Penguins, fur seals and fishing: prey requirements and potential competition in the South Shetland Islands, Antarctica. Polar Biol 19:365-374

Daly KL (1990) Overwintering development, growth, and feeding of larval Euphasia superba in the Antarctic marginal ice zone. Limnol Oceanogr 35:1564-1576

Daly KL (1998) Physioecology of juvenile Antarctic krill (Euphausia superba) during spring in ice-covered seas. In: Lizotte M, Arrigo K (eds) Antarctic sea ice: biological processes, interactions and variability. Antarct Res Ser 73. American Geophysical Union, Washington, DC, p 183-198

* Demer DA, Conti SG (2005) New target-strength model indicates more krill in the Southern Ocean. ICES J Mar Sci 62:25-32

Demer DA, Hewitt RP (1995) Bias in acoustic biomass estimates of Euphausia superba due to diel vertical migration. Deep-Sea Res I 42:455-475
Dorman JG, Sydeman WJ, García-Reyes M, Zeno RA, Santora JA (2015) Modeling krill aggregations in the centralnorthern California Current. Mar Ecol Prog Ser 528: 87-99

* Dunn MJ, Silk JRD, Trathan PN (2011) Post-breeding dispersal of Adelie penguins (Pygoscelis adeliae) nesting at Signy Island, South Orkney Islands. Polar Biol 34: 205-214

Fielding S, Watkins J, Cossio A, Reiss C and others (2011) The ASAM 2010 assessment of krill biomass for Area 48 from the Scotia Sea CCAMLR 2000 synoptic survey. Rep No. WG-EMM-11/20. Commission for the Conservation of Antarctic Marine Living Resources (CCAMLR), Hobart

*Flores H, Atkinson A, Kawaguchi S, Krafft BA and others (2012a) Impact of climate change on Antarctic krill. Mar Ecol Prog Ser 458:1-19

*Flores H, van Franeker JA, Siegel V, Haraldsson M and others (2012b) The association of Antarctic krill Euphausia superba with the under-ice habitat. PLOS ONE 7:e31775

* Foote KG (1990) Spheres for calibrating an eleven-frequency acoustic measurement system. J Cons Int Explor Mer 46: 284-286

F Forcada J, Trathan PN, Boveng PL, Boyd IL and others (2012) Responses of Antarctic pack-ice seals to environmental change and increasing krill fishing. Biol Conserv 149:40-50

*Gordon AL, Nowlin WD (1978) The basin waters of the Bransfield Strait. J Phys Oceanogr 8:258-264

*Gordon AL, Mensch M, Dong Z, Smethie WM Jr, deBettencourt J (2000) Deep and bottom water of the Bransfield Strait eastern and western basins. J Geophys Res Oceans 105:11337-11346

Gutt J, Bertler N, Bracegirdle TJ, Buschmann A and others (2015) The Southern Ocean ecosystem under multiple climate change stresses-an integrated circumpolar assessment. Glob Change Biol 21:1434-1453

Hewitt RP, Watkins J, Naganobu M, Sushin V and others (2004) Biomass of Antarctic krill in the Scotia Sea in January/February 2000 and its use in revising an estimate of precautionary yield. Deep-Sea Res II 51:1215-1236

Hill SL, Reid K, Thorpe SE, Hinke J, Watters GM (2007) A compilation of parameters for ecosystem dynamics models of the Scotia Sea-Antarctic Peninsula region. CCAMLR Sci 14:1-25

Hill SL, Phillips T, Atkinson A (2013) Potential climate change effects on the habitat of Antarctic krill in the Weddell Quadrant of the Southern Ocean. PLOS ONE 8: e72246

Hinke JT, Polito MJ, Goebel ME, Jarvis S and others (2015) Spatial and isotopic niche partitioning during winter in chinstrap and Adélie penguins from the South Shetland Islands. Ecosphere 6:125

*Hinke JT, Cossio AM, Goebel ME, Reiss CS, Trivelpiece WZ, Watters GM (2017) Identifying risk: concurrent overlap of the Antarctic krill fishery with krill-dependent predators in the Scotia Sea. PLOS ONE 12:e0170132

*Holm-Hansen O, Lorenzen CJ, Holmes RW, Strickland JDH (1965) Fluorometric determination of chlorophyll. J Cons Int Explor Mer 30:3-15

IPCC (Intergovernmental Panel on Climate Change) (2007) Climate change 2007: impacts, adaptation and vulnerability. Contribution of Working Group II to the Fourth Assessment Report of the Intergovernmental Panel on Climate Change. Cambridge University Press, Cambridge * Jiang M, Charette MA, Measures CI, Zhu Y, Zhou M (2013) 
Seasonal cycle of circulation in the Antarctic Peninsula and the off-shelf transport of shelf waters into southern Drake Passage and Scotia Sea. Deep-Sea Res II 90:15-30

Jolly GM, Hampton I (1990) A stratified random transect design for acoustic surveys of fish stocks. Can J Fish Aquat Sci 47:1282-1291

Kawaguchi S, Ishida A, King R, Raymond B and others (2013) Risk maps for Antarctic krill under projected Southern Ocean acidification. Nat Clim Change 3:843-847

Lascara CM, Hofmann EE, Ross RM, Quetin LB (1999) Seasonal variability in the distribution of Antarctic krill, Euphausia superba, west of the Antarctic Peninsula. Deep-Sea Res I 46:951-984

Laws RM (1977) Seals and whales of the Southern Ocean. Philos Trans R Soc B 279:81-96

Lawson GL, Wiebe PH, Ashjian CJ, Stanton TK (2008a) Euphausiid distribution along the Western Antarctic Peninsula-Part B: distribution of euphausiid aggregations and biomass, and associations with environmental features. Deep-Sea Res II 55:432-454

Lawson GL, Wiebe PH, Stanton TK, Ashjian CJ (2008b) Euphausiid distribution along the Western Antarctic Peninsula-Part A: development of robust multi-frequency acoustic techniques to identify euphausiid aggregations and quantify euphausiid size, abundance, and biomass. Deep-Sea Res II 55:412-431

* Lea MA, Guinet C, Cherel Y, Hindell M, Dubroca L, Thalmann S (2008) Colony-based foraging segregation by Antarctic fur seals at the Kerguelen Archipelago. Mar Ecol Prog Ser 358:273-287

Loeb V, Siegel V, Holm-Hansen O, Hewitt R, Fraser W, Trivelpiece W, Trivelpiece S (1997) Effects of sea-ice extent and krill or salp dominance on the Antarctic food web. Nature 387:897-900

Mackintosh NA (1972) Life cycle of Antarctic krill in relation to ice and water conditions. Discov Rep 36:1-94

Mauchline J (1980) Measurement of body length of Euphausia superba Dana. BIOMASS Handb 4:9

Melbourne-Thomas J, Corney SP, Trebilco R, Meiners KM and others (2016) Under ice habitats for Antarctic krill larvae: Could less mean more under climate warming? Geophys Res Lett 43:10322-10327

Meyer B (2012) The overwintering of Antarctic krill, Euphausia superba, from an ecophysiological perspective. Polar Biol 35:15-37

Nicol S, Foster J (2016) The fishery for Antarctic krill - its current status and management regime. In: Siegel V (ed) Biology and ecology of Antarctic krill. Springer, Cham, p 387-421

Nicol S, Pauly T, Bindoff NL, Wright S and others (2000) Ocean circulation off east Antarctica affects ecosystem structure and sea-ice extent. Nature 406:504-507

Nicol S, Foster J, Kawaguchi S (2012) The fishery for Antarctic krill - recent developments. Fish Fish 13:30-40

Nowacek DP, Friedlaender AS, Halpin PN, Hazen EL and others (2011) Super-aggregations of krill and humpback whales in Wilhelmina Bay, Antarctic Peninsula. PLOS ONE 6:e19173

Piñones A, Fedorov AV (2016) Projected changes of Antarctic krill habitat by the end of the 21 st century. Geophys Res Lett 43:8580-8589

Reiss CS, Cossio AM, Loeb V, Demer DA (2008) Variations in the biomass of Antarctic krill (Euphausia superba) around the South Shetland Islands, 1996-2006. ICES J Mar Sci 65:497-508
Reiss CS, Hewes CD, Holm-Hansen O (2009) Influence of atmospheric teleconnections and Upper Circumpolar Deep Water on phytoplankton biomass around Elephant Island, Antarctica. Mar Ecol Prog Ser 377:51-62

Reiss CS, Walsh J, Dietrich K, Santora JA (2014) Winter distribution and condition of Antarctic krill in relation to sea-ice and water column production in the South Shetland Islands during Austral Winter 2013. Rep No. WGEMM-14/13. Commission for the Conservation of Antarctic Marine Living Resources (CCAMLR), Hobart

Ribic C, Ainley DG, Fraser WR (1991) Habitat selection by marine mammals in the marginal ice zone. Antarct Sci 3: 181-186

Ribic CA, Chapman E, Fraser WR, Lawson GL, Wiebe PH (2008) Top predators in relation to bathymetry, ice and krill during austral winter in Marguerite Bay, Antarctica. Deep-Sea Res II 55:485-499

Ross RM, Quetin LB, Newberger T, Shaw CT, Jones JL, Oakes SA, Moore KJ (2014) Trends, cycles, interannual variability for three pelagic species west of the Antarctic Peninsula 1993-2008. Mar Ecol Prog Ser 515:11-32

* Saba GK, Fraser WR, Saba VS, Iannuzzi RA and others (2014) Winter and spring controls on the summer food web of the coastal West Antarctic Peninsula. Nat Commun 5:4318

* Santora JA (2013) Dynamic intra-seasonal habitat use by Antarctic fur seals suggests migratory hotspots near the Antarctic Peninsula. Mar Biol 160:1383-1393

* Santora JA (2014) Environmental determinants of top predator distribution within the dynamic winter pack ice zone of the northern Antarctic Peninsula. Polar Biol 37: 1083-1097

* Santora JA, Reiss CS (2011) Geospatial variability of krill and top predators within an Antarctic submarine canyon system. Mar Biol 158:2527-2540

Santora JA, Veit RR (2013) Spatio-temporal persistence of top predator hotspots near the Antarctic Peninsula. Mar Ecol Prog Ser 487:287-304

* Santora JA, Sydeman WJ, Schroeder ID, Reiss CS and others (2012) Krill space: a comparative assessment of mesoscale structuring in polar and temperate marine ecosystems. ICES J Mar Sci 69:1317-1327

Savidge DK, Amft JA (2009) Circulation on the West Antarctic Peninsula derived from 6 years of shipboard ADCP transects. Deep-Sea Res I 56:1633-1655

Schmidt K, Atkinson A, Steigenberger S, Fielding S and others (2011) Seabed foraging by Antarctic krill: implications for stock assessment, bentho-pelagic coupling, and the vertical transfer of iron. Limnol Oceanogr 56: 1411-1428

Schmidt K, Atkinson AA, Pond DW, Ireland KA (2014) Feeding and overwintering of Antarctic krill across its major habitats: the role of sea ice cover, water depth, and phytoplankton abundance. Limnol Oceanogr 59:17-36

* Schofield O, Ducklow HW, Martinson DG, Meredith MP, Moline MA, Fraser WR (2010) How do polar marine ecosystems respond to rapid climate change? Science 328: 1520-1523

Siegel V (1988) A concept of seasonal variation of krill (Euphausia superba) distribution abundance west of the Antarctic peninsula. In: Sahrhage D (ed) Antarctic Ocean and resources variability. Springer-Verlag, Berlin, p 219-230

Siegel V (1989) Winter and spring distribution and status of the krill stock in Antarctic Peninsula waters. Arch 
FischWiss 39:45-72

Siegel V (2005) Distribution and population dynamics of Euphausia superba: summary of recent findings. Polar Biol 29:1-22

Siegel V (2013) Antarctic krill populations in the outflow region of the north-western Weddell Sea. Rep No. SCCAMLR-WG-EMM-13/24. Commission for the Conservation of Antarctic Marine Living Resources (CCAMLR), Hobart

Siegel V, Reiss CS, Dietrich KS, Haraldsson M, Rohardt G (2013) Distribution and abundance of Antarctic krill (Euphausia superba) along the Antarctic Peninsula. DeepSea Res I 77:63-74

Simard Y, Lavoie D (1999) The rich krill aggregation of the Saguenay - St. Lawrence Marine Park: hydroacoustic and geostatistical biomass estimates, structure, variability, and significance for whales. Can J Fish Aquat Sci 56: 1182-1197

Siniff DB, Garrott RA, Rotella JJ, Fraser WR, Ainley DG (2008) Projecting the effects of environmental change on Antarctic seals. Antarct Sci 20:425-435

Smetacek V, Nicol S (2005) Polar ocean ecosystems in a changing world. Nature 437:362-368

Stammerjohn SE, Martinson DG, Smith RC, Iannuzzi RA (2008a) Sea ice variability in the western Antarctic Peninsula region: spatiotemporal variability from ecological and climate change perspectives. Deep-Sea Res II 55:2041-2058

Stammerjohn SE, Martinson DG, Smith RC, Yuan X, Rind D (2008b) Trends in Antarctic annual sea ice retreat and advance and their relation to El Nino-Southern Oscillation and Southern Annular Mode variability. J Geophys Res Oceans 113:C03S90

Stepnik R (1982) All-year populational studies of Euphausiacea (Crustacea) in the Admiralty Bay (King George Island, South Shetland Islands Antarctic). Pol Polar Res 3: 49-68

Stevick PT, Aguayo A, Allen J, Avila IC and others (2004) Migrations of individually identified humpback whales between the Antarctic Peninsula and South America. J Cetacean Res Manag 6:109-113

Thompson AF, Youngs MK (2013) Surface exchange

Editorial responsibility: Marsh Youngbluth,

Fort Pierce, Florida, USA between the Weddell and Scotia Seas. Geophys Res Lett 40:5920-5925

Thompson AF, Heywood KJ, Thorpe SE, Renner AHH, Trasviña A (2009) Surface circulation at the tip of the Antarctic Peninsula from drifters. J Phys Oceanogr 39: $3-26$

* Trivelpiece WZ, Hinke JT, Miller AK, Reiss CS, Trivelpiece SG, Watters GM (2011) Variability in krill biomass links harvesting and climate warming to penguin population changes in Antarctica. Proc Natl Acad Sci USA 108: 7625-7628

* von Gyldenfeldt AB, Fahrbach E, García MA, Schröder M (2002) Flow variability at the tip of the Antarctic Peninsula. Deep-Sea Res II 49:4743-4766

Worby AP, Comiso JC (2004) Studies of the Antarctic sea ice edge and ice extent from satellite and ship observations. Remote Sens Environ 92:98-111

Worby A, Allsion I, Dirita V (1999) A technique for making ship-based observations of Antarctic sea ice thickness and characteristics. Part I and II. Res Rep 14. Antarctic Cooperative Research Center, University of Tasmania, Hobart

Yuan X, Li C (2008) Climate modes in southern high latitudes and their impacts on Antarctic sea ice. J Geophys Res Oceans 113:C06S91

Z Zhou M, Dorland RD (2004) Aggregation and vertical migration behavior of Euphausia superba. Deep-Sea Res II 51: 2119-2137

Zhou M, Nordhausen W, Huntley M (1994) ADCP measurements of the distribution and abundance of euphausiids near the Antarctic Peninsula in winter. Deep-Sea Res I 41:1425-1445

Zhou M, Niiler P, Hu JH (2002) Surface currents in the Bransfield and Gerlache Straits, Antarctica. Deep-Sea Res I 49:267-280

Khou M, Niiler PP, Zhu Y, Dorland RD (2006) The western boundary current in the Bransfield Strait, Antarctica. Deep-Sea Res I 53:1244-1252

Zuur AF, Ieno EN, Walker NJ, Saveliev AA, Smith GM (2009) Mixed effects models and extensions in ecology with R. Springer Science+Business Media, New York, NY

Submitted: September 28, 2016; Accepted: February 17, 2017 Proofs received from author(s): March 17, 2017 